ISSN:2656-4270 (Online) 1410-4466 (Print) Accredited by Ministry of Research, Technology, and Higher Education with the ranking of Sinta (S4) SK NO.28/E/KPT/2019, 26th September 2019
Buletin Penelitian Sosial Ekonomi Pertanian Fakultas Pertanian Universitas Haluoleo

2021:23(1):37-43

http://ojs.uho.ac.id/index.php/sosek

doi: http://dx.doi.org/10.37149/sosek.v23i1.17491

\title{
FEASIBILITY ANALYSIS OF CASSAVA FARMING INCOME IN MOJO VILLAGE, CLUWAK SUB-DISTRICT PATI DISTRICT CENTRAL JAVA
}

\author{
Yohanes Wisnu Tresnanto ${ }^{1 *}$, Bayu Nuswantara ${ }^{1)}$ \\ ${ }^{1}$ Universitas Kristen Satya Wacana \\ *Corresponding author: 522014601@student.uksw.edu
}

To cite this article:

Tresnanto, Y., \& Nuswantara, B. (2021). Feasibility Analysis of Cassava Farming Income in Mojo Village, Cluwak

Sub-District Pati District Central Java. Buletin Penelitian Sosial Ekonomi Pertanian Fakultas Pertanian Universitas Haluoleo, 23(1), 37 - 43. doi:http://dx.doi.org/10.37149/bpsosek.v23i1.17491

Received: April 05, 2021; Accepted: April 29, 2021; Published: April 30, 2021

\begin{abstract}
The research objective was to obtain an overview of farming costs and revenue and analyze the feasibility of cassava farming income in Mojo Village. The research was conducted from March 2019 to April 2019. The type of research was descriptive quantitative. The sampling technique used is a simple random sampling technique to determine the number of samples using the Slovin formula with an error rate of $10 \%$ with a sample of 53 farmers as respondents. Data analysis techniques include cost analysis, revenue analysis, and business feasibility analysis R/C Ratio and Break-Even Point. Data types use primary and secondary data with data collection techniques using interviews, observation, questionnaires, and literature study. The results showed that the total cost was IDR10.836.545, revenue was IDR39.865.508, and income was IDR29.028.963 per hectare in 1 planting season. The feasibility of cassava farming is based on the Revenue Cost Ratio $(R / C)$ of 3.68, which means that cassava farming is feasible to be implemented. The Break-Even Point shows that the production BEP is $8.014 \mathrm{~kg}$, the price BEP is IDR383. In comparison, the average production of cassava farming in Mojo Village is $28.424 \mathrm{~kg}$, with an average price per $\mathrm{kg}$ of IDR1.403, more significant than the calculated value. BEP for production and BEP for a price indicate that cassava farming is feasible to be implemented.
\end{abstract}

Keywords: BEP; cassava; cost; revenue; $\mathrm{R} / \mathrm{C}$ ratio

\section{INTRODUCTION}

In Indonesia, cassava has an essential role as the 3rd staple food after rice and corn, consumed daily and is the staple food most consumed by households (Saediman et al., 2016; Yunus et al., 2020). The role of cassava is becoming increasingly large related to its usefulness in the industrial sector, both small, medium and large industries, not limited to domestic industry, but also in other countries as a mainstay export commodity because it has excellent added value (Suprapti, 2010). 2005; Wulandari et al., 2018). Cassava is currently an industrial commodity such as tapioca flour, fermentation, and food. Besides that, cassava is a mixed feed ingredient. Cassava is one of the potential food crop commodities to be developed in the Pati District. According to data (BPS, 2015), Pati District is the District/City with the highest cassava productivity in Central Java at 43.55 tons/ha, with a production of 661.975 tons and harvested area of 15.200 ha. Cluwak sub-district is the district with the fourth largest cassava harvested area in Pati District with 2.547 ha after Tlogowungu (3.642ha), Gembong (2.671ha) and Gunungwungkal (2.581ha). Meanwhile, Mojo Village is the village with the highest cassava production in Cluwak District. With a cassava planting area of 367 hectares, harvested area of 353 hectares and production of 10,881 tons.

A common problem in cassava cultivation is the selling price of cassava which is still unstable every year. If the price of cassava falls, the profits obtained by cassava farmers will also decrease. The low price at the market level is caused by market play. The majority of farmers cultivate cassava because it is easy to market (Andriani et al., 2018), but farmers' bargaining position is weak. In the marketing of cassava production, two systems are often used, namely selling through intermediaries and selling directly to big dealers. The two marketing systems have their respective advantages and 
disadvantages. This study aimed to obtain an overview of the farming costs and revenues of cassava farming and analyze the feasibility of farmers' income from cassava farming in Mojo Village, Cluwak District, Pati District.

\section{MATERIALS AND METHODS}

The place of this research will be carried out in Mojo Village, Cluwak District, Pati District. The location of this study was chosen with the consideration that Mojo Village is the largest cassava producing area in Cluwak District and has active farmer groups in the Cluwak District, Pati District. The research time was carried out from March to April 2019 for approximately one month (30 days).

This type of research is descriptive quantitative to describe the cost, acceptance and feasibility of farm income using survey methods. Determination of the sample using simple random sampling. The total population of cassava farmers in Mojo Village, Cluwak District, Pati District is 110 people. The determination of the number of samples uses the Slovin formula with an error rate of $10 \%$ so that the number of samples is 53 respondents. The data collection method used interviews to collect data through the topic of direct answers to respondents related to data and information about the amount of input use, input prices, and other questions related to the analysis of cassava farming, observations to collect, observe the state of cassava farming and study literature directly to obtain data through books, journals related to the topic of discussion and as a reference in this study.

The number of costs, revenues and income on cassava farming in Mojo Village can be determined using the formula according to (Soekartawi, 2002), namely:

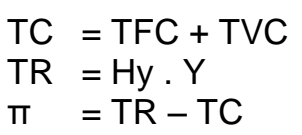

$\pi \quad=\mathrm{TR}-\mathrm{TC}$

Where, TC: Total Cost, TFC: Total Fixed Cost, TVC: Total Variable Cost, TR: Total Revenue, Y: Quantity (Sales Volume), Hy: Price (Selling Price), and m: Income

Feasibility analysis of farming using R/C Ratio, unit Break-Even Points and Price Break-Even Points. The following is the formulation of Revenue Cost Ratio (R/C) according to (Soekartawi, 2002):

$\mathrm{R} / \mathrm{C}=\mathrm{TR} / \mathrm{TC}$

Where R/C: Revenue Cost Ratio, TR: Total Revenue, TC: Total Cost,

The value of $R / C$ theoretically shows that every one rupiah of costs incurred will receive revenue. The decision criteria used to assess the results of the $R / C$ ratio analysis can be divided into three major parts, including: $\mathrm{R} / \mathrm{C}>1$ = profitable farming, $\mathrm{R} / \mathrm{C}=1$ = break-even farming, $\mathrm{R} / \mathrm{C}<1=$ farming loss

The formula for calculating Break-Even Point Production (BEP Production) according to (Soekartawi, 2005):

$B E P=T C / P$

Where, BEP: Break-Even Point (Kg), TC: Total Cost / Average Total Cost (IDR), P: Price / Average Selling Price (IDR/Kg). Criteria: If the average amount of production $>$ the average BEP of production, farming is feasible because farmers get profits. If the average amount of production $<$ the average BEP of production, then farming is impossible because the farmers are in a state of loss. Suppose the average amount of production $=$ the average BEP of production, the farm is said to break even. 2005):

The formula for calculating Break-Even Point Price (BEP Price) according to (Soekartawi,

$\mathrm{BEP}=\mathrm{TC} / \mathrm{Y}$

Where, BEP: Break-Even Point (IDR/Kg), TC: Total Cost / Average Total Cost (IDR), Y: Average production obtained from farming $(\mathrm{Kg})$. Criteria: If the product's price> BEP price, then the farm is feasible because the farmer gets the profit. If the product price < BEP price, the farm is not possible because the farmer is in a state of break-even/loss. If the product price = BEP price, then the farm is said to break even. 


\section{RESULTS AND DISCUSSION}

\section{Characteristics of Respondents}

The characteristics of the respondents in this study consisted of age, education level, land area, land ownership status and length of endeavour, as in Table 1

Table 1. Characteristics of cassava farmers

\begin{tabular}{|c|c|c|}
\hline \multirow{2}{*}{ Characteristics } & \multicolumn{2}{|c|}{ Cassava Farmer } \\
\hline & Number of farmers & Percentage (\%) \\
\hline \multicolumn{3}{|l|}{ Age (Years) } \\
\hline $25-34$ & 0 & 0 \\
\hline $35-44$ & 14 & 26 \\
\hline $45-54$ & 24 & 45 \\
\hline $55-64$ & 14 & 26 \\
\hline$\geq 65$ & 1 & 2 \\
\hline \multicolumn{3}{|l|}{ Level of education } \\
\hline Not completed in primary school & 6 & 11 \\
\hline Primary school & 10 & 19 \\
\hline Junior high school & 24 & 45 \\
\hline Senior High School & 11 & 21 \\
\hline College & 2 & 4 \\
\hline \multicolumn{3}{|l|}{ Area (hectare) } \\
\hline$\leq 0,49$ & 23 & 43 \\
\hline $0,5-1,00$ & 19 & 36 \\
\hline$\geq 1,01$ & 11 & 21 \\
\hline \multicolumn{3}{|l|}{ Land Status } \\
\hline One's own & 49 & 92,5 \\
\hline Rent & - & - \\
\hline Own \& Rent & 4 & 7,5 \\
\hline \multicolumn{3}{|l|}{ Length of Farming (Years) } \\
\hline$<5$ & 2 & 4 \\
\hline $5-10$ & 12 & 23 \\
\hline$>10$ & 39 & 74 \\
\hline
\end{tabular}

Source: Primary Data Analysis, 2019

Characteristics of respondents based on age are very diverse, ranging from 37 - 66 years, with an average age of 50 . The following is the age distribution of cassava farmers who become respondents, presented in Table 1. Table 1 shows that the age of respondent farmers is dominated by 45-54 years, totalling 24 people with a percentage of $45 \%$. At that age, the physical condition of the farmers is still in good condition. Still, there is one respondent with a non-productive age of 67 years with the percentage of $2 \%$ of all respondent farmers who still run cassava farming because cassava farming has become a habit from the past and is difficult to abandon and becomes a link in cassava farming activities (Wunawarsih \& Suriana, 2011).

The characteristics of respondents based on education level are respondents' identity based on the last formal education obtained by farmers. The following is the distribution of the education level of cassava farmers who become respondents, presented in Table 1. Based on Table 1, it can be seen that the majority of cassava farmers in Mojo Village have an education level of junior high school graduation with a percentage of $45 \%$. This shows that farmers lack human resources with a high level of education. People with higher education levels tend to choose jobs in other fields considered more secure than farming.

The average land area of respondent farmers is 0.82 ha. The most extensive land is 5 ha, while the narrowest ground is 0.1 ha. The following is the distribution of land area of cassava farmers presented in Table 1. Based on Table 1, as many as $43 \%$ of the total respondent farmers have an area of less than 0.49 ha, as many as $36 \%$ have an area of $0.5-1.00$ ha, and the remaining $21 \%$ of the total farmers have an area of more than 1.01 ha. Ha. Large land is more efficient than narrow land because the use of inputs tends to be excessive in farming with narrow land, affecting the cost and income.

The land ownership status of respondent farmers is their land, and there are farmers who, in addition to owning their land, also add land by renting land. The following is the distribution of the land 
ownership status of respondent farmers in Mojo Village, which can be seen in Table 1. Based on Table 1, it can be seen that farmers nominated the land ownership status of the respondent farmers with their land by $92.5 \%$ or 49 respondents, while the remaining $7.5 \%$ or as many as four farmer respondents are owning their land and renting land belonging to others. Farmers with their land will incur fewer costs because they do not need to pay rent. They only need to bear the cost of land taxes.

Farming experience is divided into three categories, namely less experienced ( $<5$ years), moderately experienced (5-10 years) and experienced (>10 years) (Soeharjo \& Patong, 1999). To find out the characteristics of respondents according to the experience of cassava farming in Mojo Village, it can be seen in Table 1 below. From Table 1, it can be seen that the farming experience of the respondent farmers is dominated by experienced respondent farmers who have been doing cassava farming for more than ten years as many as $74 \%$ or as many as 39 farmers, pretty experienced farmers are $23 \%$ or as many as 12 farmers. The rest farmers are classified as less experienced by $4 \%$ or as many as 2 sample farmers. Experienced farmers can have more ability to carry out production activities than less experienced farmers, but there are also other factors in the success of agricultural production.

\section{Cassava Farming Cost}

Costs are classified into fixed costs and variable costs. To balance the different prices due to differences in land area of the 53 sample farmers, each cost component has been averaged and converted into a one-hectare area. The following is the cost structure of cassava farming, which can be seen in Table 2.

Table 2. The cost structure of cassava farming

\begin{tabular}{|c|c|c|}
\hline \multirow{2}{*}{ Cost component } & \multicolumn{2}{|c|}{ Cost Description } \\
\hline & Value (IDR/ha) & Percentage (\%) \\
\hline \multicolumn{3}{|l|}{ A. Fixed Cost } \\
\hline - Property tax & 79.563 & 0.73 \\
\hline Sub Total & 79.563 & 0.73 \\
\hline \multicolumn{3}{|l|}{ B. Variable Cost } \\
\hline - Seeds & 1.138 .683 & 10.51 \\
\hline - Urea Fertilizer & 398.070 & 3.67 \\
\hline - Phonska Fertilizer & 701.139 & 6.47 \\
\hline - Organic fertilizer & 139.082 & 1.28 \\
\hline Herbicide & 147.973 & 1.37 \\
\hline - Tractor Rental & 619.770 & 5.72 \\
\hline - Labor & 5.595 .842 & 51.64 \\
\hline - Consumption & 1.618 .488 & 14.94 \\
\hline - Equipment Depreciation & 397.936 & 3.67 \\
\hline Sub Total & 10.756 .982 & 99.27 \\
\hline Total cost & 10.836 .545 & 100 \\
\hline
\end{tabular}

Source: Primary Data Analysis, 2019

The fixed cost component consists of land tax expense and equipment depreciation expense. The average use of equipment includes six hoe units, six machete units, and two sprayer units. The hoe tool has an economic life of 4.6 years, the machete is 4.3 years, and the sprayer is seven years. The depreciation cost of farm equipment owned is calculated using the straight-line method, assuming the residual value of the equipment is zero rupiahs. The variable cost components include seed costs, fertilizer costs, herbicides, labour, equipment depreciation, tractor rental, harvest truck rental and consumption. The seeds used are varieties of UJ-3, UJ-5 and Daplang, which are categorized as bitter cassava. The average number of sources is 45.5 bunches, or equal to 10,248 pieces of seeds.

The moderate use of organic fertilizer is $695.41 \mathrm{~kg}$. Based on a survey conducted by the author, livestock manure is sold for IDR. 200 per $\mathrm{kg}$. At the same time, the types of inorganic fertilizers that respondent farmers often use are Urea fertilizer as much as $221.15 \mathrm{~kg}$ and Phonska (NPK), as much as $304.84 \mathrm{~kg}$. The herbicides used by respondent farmers are Roundup and Gramoxone products. One of the reasons for using herbicides is to replace manual weed control or to weed. Of course, this can reduce costs. In the use of herbicides, it takes an average of $2.224 \mathrm{ml}$ per hectare. Respondent farmers have limitations in tractor ownership, so farmers have to pay tractor rental costs for land preparation and planting preparation. 
Generally, respondent farmers rent based on daily calculations where the processing of 1hectare land can be completed in 2 days. Consumption includes lunch, cigarettes and coffee with an average cost of IDR 1.618 .488 for 68 HOK. The use of labour is calculated in units of working days (HOK) for eight work hours. Respondent farmers only use male labour in the cultivation process. Activities carried out by farm labourers include land processing, planting, fertilizing, weeding, embroidery. While nine respondent farmers only use post-harvest transportation workers out of 53 respondents, 44 other respondent farmers sell their harvests to collectors. In one planting season, it takes a total daily workforce (HOK) of 68.4 people. In other words, labour costs are the most significant costs incurred, with a presentation of $51.64 \%$ of the total cost of cassava farming. Additional costs refer to costs that have few users, so they are less accurate and not good enough to describe the average use of these variables. Other costs include land rental fees and harvest truck rentals. Of the 53 respondent farmers, four respondent farmers use leased land even though they also have land.

Meanwhile, the rental of harvest trucks is carried out by respondent farmers who sell their products to big cities. As many as nine respondent farmers use harvest truck rental services. The remaining 44 respondent farmers do not use harvest truck rental services because middlemen directly take the harvest. On average, in 1 hectare of land, it requires as much as 5.02 times to transport harvest trucks. Therefore, other costs are not included in the calculation of the cost analysis.

The biggest cost incurred by farmers in farming is the labour costs of IDR5.595.842 or $51.64 \%$ of the total cost of IDR10.836.545. For comparison, research (Siregar, Ginting, \& Jufri, 2015) has a total cost of IDR. 9.908.042 with the seed variable as the cost with the largest presentation $(50.47 \%)$ or IDR5.000.000, in research (Muizah, Supardi, \& Awami, 2013) the total cost is IDR7.824.782 with labor as the largest cost $(45.07 \%)$ or IDR 3.526.900, while in research (Simamora, Nababan, \& Pakpahan, 2018) the total cost is IDR 10.437.133. This shows that the costs incurred by respondent farmers in Mojo Village are slightly larger, possibly due to differences in the use of inputs, the occurrence of inflation which affects the value of the price of an item or service, especially when compared to research that has been carried out for a long time.

\section{Cassava Farming Acceptance}

Farming receipts received by cassava farmers in Mojo Village are cash receipts. There are two marketing systems for cassava in Mojo Village. The following cassava marketing system can be seen in the following Figure 1:

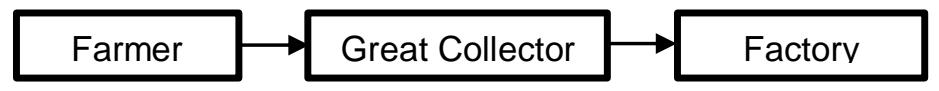

Figure 1. The first marketing system of cassava in Mojo Village

In the first marketing system, farmers sell directly to big dealers and then sold to industries or factories. From 53 respondent farmers, nine respondent farmers use the first marketing system. Determination of the selling price of farmers to big cities is measured based on the weight of the harvest following the market price. Seller farmers carry out the harvesting and transportation process, using harvest labour and renting trucks to transport the harvested produce to the big city. Many large airports are located in industrial areas or tapioca factories in Margoyoso District, Trangkil District and surrounding areas. The industry, in this case, is the final consumer because it buys cassava as a raw material for its products.

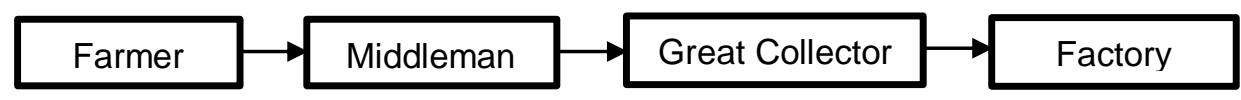

Figure 2. The second marketing system of cassava in Mojo Village

In the second marketing system, farmers sell their crops through middlemen. As many as 44 respondents out of 53 respondents, most respondent farmers used the dual marketing system. The selling price of farmers to middlemen is determined based on estimates. Buying and selling transactions are carried out before harvesting is carried out. The whole harvesting process is borne by the middlemen, from harvesting labour to transportation. Many farmers choose the second marketing system due to the limited relationship between farmers and big airports in marketing their crops, the difficulty of finding harvesters and more efficient labour for farmers who have narrow land so that farmers prefer to sell their harvests through middlemen.

The income obtained from the two marketing systems is different. The first marketing system gets a lower price than the dual marketing system. Still, farmers do not have to bother to market their 
crops compared to the second harvest system in the first marketing system. The average production obtained by farmers in Mojo Village is $28.424 \mathrm{~kg}$ per hectare per planting season, while the average income from farming is IDR39.865.508 for IDR1.403/kg per hectare per growing season. For comparison, the research (Siregar et al., 2015) has a total production of $21.018 \mathrm{~kg}$. The price is IDR1.308/kg with total revenue of IDR27.500.000. The study (Muizah et al., 2013) has a total production of $19.378 \mathrm{~kg}$, the price is IDR867/ $\mathrm{kg}$ with total revenue of IDR16.858.800, while the research (Simamora et al., 2018) totals IDR. 31.145.000. This shows that the income received by respondent farmers in Mojo village is relatively high. This is possibly due to the unstable price each year. In the year this research was carried out, cassava in Mojo Village had a good price for farmers and cassava productivity. In the village of Mojo, which is quite high.

\section{Income and Revenue Cost Ratio (R/C)}

Total farm income is the difference between total revenue and total costs incurred in cassava farming. The following is the average calculation of cassava farming income in Mojo Village in Table 3.

Table 3. Average results of total cassava farming income

\begin{tabular}{lc}
\multicolumn{1}{c}{ Description (average) } & Total \\
\hline Total Receipts (IDR) & 39.865 .508 \\
Total Production Cost (IDR) & 10.836 .545 \\
Total Income (IDR) & 29.028 .963 \\
R/C Ratio & 3.68 \\
\hline
\end{tabular}

Source: Primary Data Analysis, 2019

Based on Table 3, it can be seen that the income of cassava farming in Mojo Village is IDR. 29.028.963, which is generated from the total revenue of IDR. 39.865.508 minus the total production cost of IDR. 10.836.545. The income of the respondents is strongly influenced by the variable costs incurred because in running cassava farming, the use of cassava. As a comparison with research (Siregar et al., 2015) has a total income of IDR. 17.591.957, in research (Muizah et al., 2013) has a total income of IDR. 9.034.018, while in research (Simamora et al., 2018) ) total income is IDR.20.707.866, and in research (Umliyah et al., 2019), total income is IDR860.116. This shows that the income obtained by respondent farmers in Mojo Village has a relatively high income. This is due to high productivity. The costs incurred are not too large compared to previous studies, and the prices are quite good so that the respondent farmers in Mojo Village get high incomes.

The level of business feasibility is measured using revenue and cost analysis (R/C Ratio) which is recommended in financial calculations. R/C is a comparison between the total revenue of the farm and the total costs incurred during the production process. Based on the analysis of 53 respondents, the average value of Revenue Cost Ratio $(R / C)$. The calculation results of Table 3 above show that the total average R/C Ratio is 3.68 or more than 1 , which means that farming is profitable. Compared with the results of previous studies, these results are greater than those of journals from (Siregar et al., 2015) which produced an R/C Ratio value of 2.79 and research from (Simamora et al., 2018) which resulted in an R/C Ratio 3.00. The difference in selling prices and production makes the results of the R/C Ratio of this study higher than the value of the R/C Ratio of previous studies. However, the difference is not significant.

\section{Break-Even Point Price and Break-Even Point Production}

The break-even point is used to determine the benchmark that must be exceeded, how much production, and the price must be created so that the run farm does not suffer losses. The following are the results of the calculation of the average BEP of Production and BEP of cassava farming prices in Mojo Village in the following Table 4

Table 4. Calculation results of average break-even point production and break-even point prices of cassava farming in Mojo Village

\begin{tabular}{|c|c|}
\hline BEP & Value \\
\hline BEP Production $(\mathrm{kg} / \mathrm{ha})$ & 8.014 \\
\hline BEP Prices (IDR/kg) & 383 \\
\hline
\end{tabular}

Source: Primary Data Analysis, 2019 
Based on Table 4, it can be seen that the average BEP production is $8.014 \mathrm{~kg}$ and the price BEP is IDR 383, while the average output from cassava farming in Mojo Village is $28.424 \mathrm{~kg}$ and has an average price per $\mathrm{kg}$ of IDR 1.403 . Thus the production and average price of cassava farming is greater than the value of the production BEP and the price BEP. This shows that cassava farming in Mojo Village can be said to be feasible for farmers.

\section{CONCLUSION}

The total cost of cassava farming in Mojo Village is IDR10.836.545, revenue for cassava farming is IDR39.865.508 and farm income is IDR29.028.963 per hectare in one growing season. The feasibility of cassava farming based on the Revenue Cost Ratio $(R / C)$ is 3.68 . This shows that cassava farming in Mojo Village is feasible to carry out. The Break-Even Point shows that the BEP production is $8.014 \mathrm{~kg}$, and the BEP price is IDR383. The average production of cassava farming in Mojo Village is $28.424 \mathrm{~kg}$, with an average price per $\mathrm{kg}$ of IDR1.403, more significant than the calculated BEP value. Production and price BEP. This shows that cassava farming in Mojo Village can be said to be feasible for farmers.

\section{REFERENCES}

Andriani, I., Iswandi, R., \& Abdi, A. (2018). Analisis Peranan dan Manfaat Kemitraan Usaha Singkong Cassesart Antara Koperasi Loh Jinawe dan PT. Cipta Agung Manis di Desa Wunduwatu Kecamatan Andoolo Kabupaten Konawe Selatan. JIA (Jurnal IImiah Agribisnis) : Jurnal Agribisnis dan IImu Sosial Ekonomi Pertanian, 3(3), 59 - 63. doi:http://dx.doi.org/10.33772/jia.v3i3.7829

BPS. (2015). Produksi Palawija, Kacang Hijau, Ubi Kayu dan Ubi Jalar Kabupaten Pati. Pati: Badan Pusat Statistik.

Muizah, R., Supardi, S., \& Awami, S. N. (2013). Analisis Pendapatan Usahatani Ubi Kayu (Manihot esculenta crantz) (Studi Kasus Desa Mojo Kecamatan Cluwak Kabupaten Pati). MEDIAGRO, VOL. 9. NO. 2. 2013. 55-67.

Saediman, H., Limi, M. A., . R., Arimbawa, P., \& Indarsyih, Y. (2016). Cassava Consumption and Food Security Status among Cassava Growing Households in Southeast Sulawesi. Pakistan Journal of Nutrition, 15(12), 1008-1016. https://doi.org/10.3923/pjn.2016.1008.1016

Simamora, D. L., Nababan, M. B., \& Pakpahan, H. T. (2018). Faktor Produksi dan Kelayakan Usahatani Ubi Kayu (Studi Kasus : Desa Medan Senembah Kecamatan Tanjung Morawa Kabupaten Deli Serdang Jurnal IImiah Skylandsea, Volume 2 No. 2 Juli 2018.

Siregar, B. C., Ginting, R., \& Jufri, M. (2015). Analisis Usahatani Ubi Kayu (Manihot Esculenta) Studi Kasus : Desa Marihat Bandar, Kecamatan Bandar, Kabupaten Simalugun. Journal On Social Economic Of Agriculture And Agribusiness, Vol 4, No 12 (2015): Volume 4 No. 12 Desember 2015.

Soeharjo, A., \& Patong, D. (1999). Sendi-Sendi Pokok IImu Usahatani. Bogor: Fakultas Pertanian Institut Pertanian Bogor.

Soekartawi. (2002). Prinsip Dasar Ekonomi Pertanian Teori dan Aplikasi. Jakarta: Raja Grafindo.

Soekartawi. (2005). Agribisnis Teori dan Aplikasinya. Jakarta: Raja Grafindo Persada.

Umliyah, G., Bahari, B., \& Limi, M. (2019). Analisis Pendapatan Usahatani Ubi Kayu pada Lahan Sub Optimal di Kecamatan Binongko Kabupaten Wakatobi. Jurnal Ilmiah Membangun Desa dan Pertanian, 4(6), 161 - 165. doi:http://dx.doi.org/10.33772/jimdp.v4i6.8125

Wulandari, f., Abdi, A., \& Rosmawaty, R. (2018). Analisis Keuntungan dan Nilai Tambah Usaha Keripik Singkong pada Usaha Home Industri "Tiga Putra Sunda" di Desa Sindangkasih Kecamatan Ranomeeto Barat Kabupaten Konawe Selatan. Jurnal IImiah Membangun Desa dan Pertanian, 3(3), 79 - 84. doi:http://dx.doi.org/10.33772/jimdp.v3i3.7968

Wunawarsih, I., \& Suriana, S. (2011). Analisis Jaringan Komunikasi dalam Alih Teknologi Pasca Panen Ubi Kayu di Desa Sabulakoa, Kecamatan Tinanggea, Kabupaten Konawe Selatan. Buletin Penelitian Sosial Ekonomi Pertanian Fakultas Pertanian Universitas Haluoleo, 13(25), 172 - 185. doi:http://dx.doi.org/10.33772/bpsosek.v13i25.5957

Yunus, L., Zani, M., \& Limi, M. A. (2020). Analysis of household food security status of cassava farmers in lapodi village, pasarwajo district, buton regency. International Journal of Scientific and Technology Research, 9(4), 581-584. 